\title{
ZINC AND THE HEAT-LABILE ENTEROTOXIN OF ESCHERICHIA COLI
}

\author{
B. SUgaRman* AND Lisa R. Epps
}

Medical Service and Spinal Cord Injury Service, Houston Veterans Administration Medical Center and the Departments of Physical Medicine and Medicine, Baylor College of Medicine, Houston, Texas, USA

\begin{abstract}
SUmmary. Enterotoxigenic Escherichia coli is a major cause of diarrhoea in man. When zinc in concentrations of $10^{-6} \mathrm{M}$ or $10^{-5} \mathrm{M}$ was added to the growth medium, there was a significant increase in heat-labile enterotoxin production by each of six toxigenic strains. Zinc in these concentrations did not alter bacterial growth or the activity of preformed toxin. Other heavy metals did not enhance toxin production and $o$-phenanthroline, a relatively specific zinc-chelating compound, blocked the enhancing effect. The significance of these findings is discussed in relation to the use of supplemental dietary zinc.
\end{abstract}

\section{INTRODUCTION}

Zinc is essential for all living organisms (Vallee, 1959; Riordan, 1976) where it functions, for example, in many metallo-enzymes, activation of biological compounds and membrane stabilisation (Reynolds and Schlesinger, 1969; Trotman and Greenwood, 1971; Chvapil, 1976; Failla, 1977). The alpha toxin of Clostridium perfringens is produced in an inactive form when the organism is grown in medium with low concentrations of zinc but it combines with zinc to form stable and active toxin (Sato and Murata, 1973; Sato et al., 1978). Several other bacteria produce increased amounts of proteases, toxins or both when incubated with supplemental zinc (Feeney, Lightbody and Garibaldi, 1947; Jensen, Fecycz and Campbell, 1980; Riddle, Graham and Amborski, 1981; Kessler et al., 1982), which probably reflects the presence of zinc in these proteins or in the nucleic-acid polymerases involved in their synthesis (Wegener and Romano, 1963; Williams and Loeb, 1973; Sugarman, 1983).

Toxigenic Escherichia coli is a major cause of diarrhoea in man (e.g., traveller's diarrhoea) and other mammals (DuPont et al., 1980; Sack, 1980; Clements, Flint and Klipstein, 1982). Loss of time from work and economic losses in the raising of infected animals can be significant. The heat-labile enterotoxin (LT) closely resembles cholera toxin (DuPont et al., 1980; Clements et al., 1982), and produces a prolonged secretory response by the intestinal cells affected (Sack, 1980).

Because zinc is so often ingested as a nutritional supplement, alone or in

Received 14 Feb. 1984; accepted 17 Apr. 1984.

* Correspondence to Dr B. Sugarman, Bldg 1A, Room 620, VA Medical Center, 2002 Holcombe Blvd, Houston, Texas USA 77030. 
proprietary vitamins-with-mineral preparations, an attempt was made to determine if zinc supplements may act as a virulence factor in the development or severity of disease caused by the LT of $E$. coli. This hypothesis is based upon aspects of zinc biochemistry mentioned above and on other data which suggest that zinc may promote some bacterial infections (Sugarman, 1983).

\section{MATERIALS AND METHODS}

Bacteria. Six LT-producing strains of $E$. coli (isolates 1, 2, and 5 also produced heat-stable toxin) were grown in a shaking apparatus for $18 \mathrm{~h}$ at $37^{\circ} \mathrm{C}$ in trypticase soy broth (TSB) (BBL, Cockeysville, MD, USA) or Eagle's minimal essential medium (MEM) (Gibco, Grand Island, NY, USA) with defined concentrations of zinc or other heavy metals. To prevent trace zinc contamination (Failla, 1977), only acid-washed glassware (Falchuck, 1977), disposable plastic-ware, reagent quality chemicals, and ultra-pure water of at least $18 \mathrm{megohm} / \mathrm{cm}$ resistivity and with no zinc detectable by atomic absorption spectrophotometry (AAS) (Perkin-Elmer, Norwalk, CT, USA)) were used for these experiments. In certain experiments; polymyxin B 2000 units/ml of medium was added and incubated for a further $30 \mathrm{~min}$ in order to lyse the cells; this reduced the viable colony counts by $>99.99 \%$. These cultures were centrifuged to remove the bacteria and supernates were filtered through $0 \cdot 2-\mu \mathrm{m}$ membrane filters (Amicon, Danvers, MA, USA). Non-LT producing control strains were treated in the same way.

$L T$ assay. LT in the supernates was assayed by the Y1 mouse adrenal cell assay (Donta, Moon and Whipp, 1974; Sack and Sack, 1975). Briefly, Y1 cells were grown at $37^{\circ} \mathrm{C}$, in a humidified atmosphere of $\mathrm{CO}_{2}, 5 \% \mathrm{v} / \mathrm{v}$ and air $95 \%$, in plastic multi-welled plates (Flow Laboratories, McLean, VI, USA) in Ham's nutrient F-10 mixture (Flow) supplemented with horse serum $15 \%$ (Flow), fetal bovine serum $2.5 \% \mathrm{v} / \mathrm{v}$ (Sterile Systems, Inc., Logan, UT, USA) and gentamicin $40 \mu \mathrm{g} / \mathrm{ml}$. When a monolayer was formed, the bacterial culture supernates were added in a 1 to 10 dilution to the medium bathing the Y1 cells and incubated in the same humidified atmosphere for up to $48 \mathrm{~h}$. Rounding of the cells was assessed with a phase-contrast microscope and was graded, without knowledge of the contents, as $0,1,2$, or 3 corresponding respectively to $<20 \%$ cells rounded, $20-49 \%$ rounded, $50-90 \%$ rounded, and $>90 \%$ rounded. Rounding of the Y1 cells as determined by light microscopy correlates with steroidogenesis by these cells and with the amount of LT present (Donta et al., 1974). This technique was highly reproducible; duplicate plates were scored exactly the same after incubation for $24 \mathrm{~h}$ in 261 of 272 sets from the same days.

In other experiments $5 \times 10^{-6} \mathrm{M} o$-phenanthroline was added to the bacterial growth medium with or without supplemental zinc. After incubation for $18 \mathrm{~h}$, cultures were centrifuged and the supernates filtered through a 10000-mol. wt ultrafiltration device (Amicon) to remove the $o$-phenanthroline. The retentates were diluted in isotonic buffer to their original volumes and assayed for LT after incubation with Y1 cells for $6 \mathrm{~h}$.

Statistical method. The signed-ranks test of Wilcoxon was used to judge statistical significance, with $\mathrm{n} \geqslant 5$.

\section{RESULTS}

\section{Zinc effect}

Supernates from non-LT producing strains of $E$. coli (controls) never produced any rounding, even when the bacteria were grown with up to $2 \times 10^{-5} \mathrm{M}$ supplemental zinc. Zinc alone added to $\mathrm{Y} 1$ cells in concentrations of up to $1 \times 10^{-4} \mathrm{M}$ never produced any rounding. In contrast, all six LT-producing strains of $E$. coli caused rounding of the Y1 cells when grown in either unsupplemented TSB or MEM. TSB contained $6.7 \times 10^{-7} \mathrm{M}$ zinc and MEM contained $1.8 \times 10^{-7} \mathrm{M}$ zinc as measured by AAS. The addition of supplemental zinc $\left(1 \times 10^{-6} \mathrm{M}\right.$ or $\left.1 \times 10^{-5} \mathrm{M}\right)$ to the TSB growth medium did not affect 
TABLE I

Assay of LT produced by E. coli strains after growth for $18 \mathrm{~h}$ in TSB with or without added zinc

\begin{tabular}{|c|c|c|c|c|c|c|c|c|c|}
\hline \multirow[b]{3}{*}{$\begin{array}{c}E . \text { coli } \\
\text { strain no. }\end{array}$} & \multicolumn{9}{|c|}{ Mean rounding score ( \pm standard deviation of the mean) in the $Y 1$ mouse adrenal cell assay after incubation for } \\
\hline & \multicolumn{3}{|c|}{$6 \mathrm{~h}$} & \multicolumn{3}{|c|}{$24 \mathrm{~h}$} & \multicolumn{3}{|c|}{$48 \mathrm{~h}$} \\
\hline & None & $\begin{array}{l}\text { with added zinc } \\
1 \times 10^{-6} \mathrm{M}\end{array}$ & $1 \times 10^{-5} \mathrm{M}$ & None & $\begin{array}{l}\text { with added zinc } \\
1 \times 10^{-6} \mathrm{M}\end{array}$ & $1 \times 10^{-5} \mathrm{M}$ & None & $\begin{array}{l}\text { with added zinc } \\
1 \times 10^{-6} \mathrm{M}\end{array}$ & $1 \times 10^{-5} M$ \\
\hline $\begin{array}{l}1 \\
2 \\
3 \\
4 \\
5 \\
6\end{array}$ & $\begin{array}{c}1 \cdot 0( \pm 0.4) \\
0( \pm 0) \\
0( \pm 0) \\
0 \cdot 3( \pm 0 \cdot 3) \\
1 \cdot 0( \pm 0 \cdot 8) \\
1 \cdot 2( \pm 0.1)\end{array}$ & $\begin{array}{c}2 \cdot 0( \pm 0.4)^{*} \\
0( \pm 0) \\
0( \pm 0) \\
0.6( \pm 0.4) \\
1.8( \pm 0.4)^{*} \\
1.7( \pm 0.5)^{*}\end{array}$ & $\begin{array}{c}2 \cdot 0( \pm 0.4)^{*} \\
0 \cdot 2( \pm 0.4) \\
0( \pm 0) \\
0 \cdot 3( \pm 0-3) \\
1 \cdot 3( \pm 0.8) \\
1 \cdot 8( \pm 0.5)^{*}\end{array}$ & $\begin{array}{l}2.2( \pm 0.5) \\
1.0( \pm 0.7) \\
1.0( \pm 0.5) \\
1.6( \pm 0.7) \\
2.3( \pm 0.7) \\
3.0( \pm 0.0)\end{array}$ & $\begin{array}{l}3.0( \pm 0.0)^{*} \\
1.2( \pm 0.7) \\
1.4( \pm 0.6) \\
2.0( \pm 0.5) \\
2.7( \pm 0.9) \\
3.0( \pm 0.0)\end{array}$ & $\begin{array}{l}3 \cdot 0( \pm 0.0)^{*} \\
2 \cdot 0( \pm 0.9)^{*} \\
1 \cdot 3( \pm 0.5) \\
2 \cdot 5( \pm 0.8)^{*} \\
2 \cdot 3( \pm 0.7) \\
3 \cdot 0( \pm 0.0)\end{array}$ & $\begin{array}{l}2.4( \pm 0.5) \\
1.2( \pm 0.8) \\
1.3( \pm 0.8) \\
2.5( \pm 0.5) \\
3.0( \pm 0.0) \\
3.0( \pm 0.0)\end{array}$ & $\begin{array}{l}3 \cdot 0( \pm 0.0)^{*} \\
1 \cdot 5( \pm 0.8) \\
1 \cdot 5( \pm 0.9) \\
2 \cdot 7( \pm 0.6) \\
3 \cdot 0( \pm 0.0) \\
3 \cdot 0( \pm 0.0)\end{array}$ & $\begin{array}{l}3.0( \pm 0.0)^{*} \\
2 \cdot 0( \pm 0.9)^{*} \\
2 \cdot 0( \pm 1 \cdot 0)^{*} \\
2 \cdot 7( \pm 0.6) \\
3 \cdot 0( \pm 0.0) \\
3.0( \pm 0.0)\end{array}$ \\
\hline
\end{tabular}

${ }^{*} \mathrm{p}<0.05$ compared to appropriate control without supplemental zinc. 
bacterial growth as assayed by viable count, but significantly increased toxin production as manifested by quicker and more rounding of the Y1 cells (table I). Results with MEM were similar, though less rounding occurred in all groups. Addition of $1 \times 10^{-6} \mathrm{M}$ or $1 \times 10^{-5} \mathrm{M}$ zinc to each of the bacterial supernates immediately before incubation with the $\mathrm{Y} 1$ cells did not result in any differences compared with control supernates without supplemental zinc. Zinc chloride was used in all of the above experiments but zinc acetate also produced the same effects.

To determine the extent of toxin enhancement and whether increased release of preformed toxin was responsible, experiments were repeated with lysis of the bacteria by polymyxin B and serial dilution of the bacterial supernates. Lysis of the bacteria greatly increased the amount of toxin present in the supernates. Growth of the different isolates with zinc caused production of more toxin, approximately $140-220 \%$ of that produced by control cultures. Representative data are shown in table II.

$O$-phenanthroline, $5 \times 10^{-6} \mathrm{M}$, a relatively specific zinc-binding compound, did not inhibit growth of the $E$. coli strains nor have any effect on LT production in unsupplemented medium. However, it did block the effect of supplemental zinc on elaboration of LT during co-incubation (table III).

\section{Other heavy metals}

Chloride salts of iron (ferrous and ferric), magnesium, manganese, zinc and

TABLE II

Assay of $L T$ after lysis of $E$. coli strains with polymyxin $B$

\begin{tabular}{|c|c|c|c|c|c|c|}
\hline \multirow{4}{*}{$\begin{array}{l}E . \text { coli } \\
\text { strain no. }\end{array}$} & \multicolumn{6}{|c|}{ Mean rounding score $(\underset{\text { incubation for } 24 \mathrm{~h} \text { with supernate }}{ \pm \text { standard deviation }) \text { in } 1 \text { mouse adrenal cell assay after }}$} \\
\hline & \multirow{2}{*}{\multicolumn{2}{|c|}{$\frac{\text { Undiluted }}{\text { with added zinc }}$}} & \multicolumn{2}{|c|}{ Diluted 1 in 10} & \multicolumn{2}{|c|}{ Diluted 1 in 20} \\
\hline & & & \multicolumn{2}{|c|}{ with added zinc } & \multicolumn{2}{|c|}{ with added zinc } \\
\hline & None & $1 \times 10^{-5} \mathrm{M}$ & None & $1 \times 10^{-5} \mathrm{M}$ & None & $1 \times 10^{-5} \mathrm{M}$ \\
\hline $\begin{array}{l}4 \\
5\end{array}$ & $\begin{array}{l}3.0( \pm 0.0) \\
3.0( \pm 0.0)\end{array}$ & $\begin{array}{l}3.0( \pm 0.0) \\
3.0( \pm 0.0)\end{array}$ & $\begin{array}{l}2 \cdot 1( \pm 0.4) \\
1 \cdot 7( \pm 0.8)\end{array}$ & $\begin{array}{l}2.7( \pm 0.5)^{*} \\
2.8( \pm 0.6)^{*}\end{array}$ & $\begin{array}{l}1 \cdot 1( \pm 0.6) \\
1.0( \pm 0.5)\end{array}$ & $\begin{array}{l}1.5( \pm 0.5)^{*} \\
1.9( \pm 0.7)^{*}\end{array}$ \\
\hline
\end{tabular}

$* \mathrm{p}<0.05$ compared to appropriate control without supplemental zinc.

TABLE III

Effect of $5 \times 10^{-6} \mathrm{M}$ o-phenanthroline on enhancement of LT production by zinc

\begin{tabular}{|c|c|c|c|c|}
\hline \multirow[b]{2}{*}{$\begin{array}{l}\text { E. coli } \\
\text { strain }\end{array}$} & \multicolumn{4}{|c|}{ 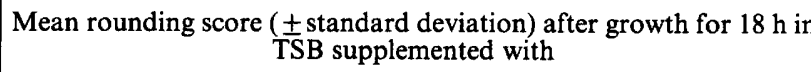 } \\
\hline & No supplement & Zinc $\ddagger$ & $\begin{array}{l}\text { Zinc }+5 \times 10^{-6} \mathrm{M} \\
o \text {-phenanthroline }\end{array}$ & $\begin{array}{c}5 \times 10^{-6} \mathrm{M} \\
o \text {-phenanthroline }\end{array}$ \\
\hline \multirow{2}{*}{$\begin{array}{l}\text { E. coli strain no. } 1 \\
\text { E. coli strain no. } 6 \\
\text { Non LT-producing } \\
\text { E. coli control }\end{array}$} & $\begin{array}{l}1.2( \pm 0.2) \\
1.1( \pm 0.1)\end{array}$ & $\begin{array}{l}2.0( \pm 0.2)^{*} \\
1.6( \pm 0.4)^{*}\end{array}$ & $\begin{array}{l}1 \cdot 0( \pm 0 \cdot 4) \\
1 \cdot 1( \pm 0 \cdot 2)\end{array}$ & $\begin{array}{l}1 \cdot 2( \pm 0 \cdot 2) \\
1 \cdot 2( \pm 0 \cdot 1)\end{array}$ \\
\hline & $0( \pm 0)$ & $0( \pm 0)$ & $0( \pm 0)$ & $0( \pm 0)$ \\
\hline
\end{tabular}

$\ddagger 1 \times 10^{-5} \mathrm{M}$ for $E$. coli strain no. 1 and control; $1 \times 10^{-6} \mathrm{M}$ for $E$. coli strain no. 6 . ${ }_{*} \mathrm{p}<0.05$ compared to control. 
calcium in final concentrations of $1 \times 10^{-6} \mathrm{M}$ and $1 \times 10^{-5} \mathrm{M}$ were incubated with $E$. coli strain no. 1 and $E$. coli strain no. 6 in TSB. After $18 \mathrm{~h}$, viable counts averaged $(1 \cdot 8-2 \cdot 1)$ $\times 10^{9} \mathrm{cfu} / \mathrm{ml}$ for each strain grown without supplemental metal; results with the metals were not statistically different, averaging $\pm 20 \%$ of the control values. Rounding of the Y1 cells after 6,24 and $48 \mathrm{~h}$ was highly reproducible, with means $\pm 10 \%$ of the controls for all metals except zinc.

\section{Discussion}

These data show that significantly more LT was produced when $E$. coli isolates were grown with $10^{-6}-10^{-5} \mathrm{M}$ supplemental zinc. Zinc in these concentrations stabilises membranes (Sugarman, 1983) and lysis of the bacteria with polymyxin greatly increased the amount of toxin in the supernates, but the effect with zinc was still noted; therefore, it seems unlikely that the effect was due solely to an increased release of LT into the surrounding milieu. The lack of effect noted when zinc was added after bacterial growth suggests that this increased toxicity was not the result of activation or stabilisation of the toxin by zinc, unless the zinc present in unsupplemented growth media was adequate for maximal effect. Most media contain at least $10^{-7} \mathrm{M}$ zinc; it is quite difficult to prepare media with less zinc, and this concentration is sufficient for optimal growth of most bacteria (Failla, 1977). The specificity of zinc to cause increased production of LT was determined by the inability of other heavy metals to cause this effect and by the inhibition of the response with a zinc chelator. The inability of $o$-phenanthroline alone to decrease LT production compared with bacteria grown without supplemental zinc suggests that only trace amounts of zinc are necessary for baseline LT production, that intracellular zinc is sufficient, or that the bacteria successfully compete with $o$-phenanthroline for zinc.

Normally, people ingest $c$. 10-15 mg of zinc daily and most of this is excreted in the faeces, the level excreted increasing with higher levels of ingestion (Sugarman, 1983). Zinc supplementation would increase the amount of zinc in the intestines and could promote the development of infection by increasing the attachment of bacteria to receptor cells (Sugarman, Epps \& Stenback, 1982), elaboration of LT, or both. Zinc supplementation should not be considered harmless until in-vivo studies of associated infection risk are conducted.

This research was supported by the Veterans Administration. Dr H. L. DuPont and his associates of the University of Texas Medical School at Houston graciously provided the toxigenic $E$. coli strains and identified those that also produced heat-stable toxin. Linda Babura provided expert secretarial assistance.

\section{REFERENCES}

Chvapil M 1976 Effect of zinc on cells and biomembranes. Medical Clinics of North America 60:799-812

Clements J D, Flint D C, Klipstein F A 1982 Immunological and physicochemical characterization of heat-labile enterotoxins isolated from two strains of Escherichia coli. Infection and Immunity 38:806-809.

Donta S T, Moon H W, Whipp S C 1974 Detection of heat-labile Escherichia coli enterotoxin with the use of adrenal cells in tissue culture. Science 183:334-336.

Dupont H L, Sullivan P, Evans D G, Pickering L K, Evans D J, Volett J J, Ericsson C D, Ackerman P B, Tjoa W S 1980 Prevention of traveler's diarrhea (emporiatric enteritis): 
prophylactic administration of subsalicylate bismuth. Journal of the American Medical Association 243:237-241.

Failla M L 1977 Zinc: functions and transport in microorganisms. In: Weinberg E D (ed) Microorganisms and minerals, Marcel Dekker, New York, pp. 151-214.

Falchuk K H 1977 Effect of acute disease and ACTH on serum zinc proteins. New England Journal of Medicine 296:1129-1134.

Feeney R E, Lightbody H D, Garibaldi J A 1947 Zinc as an essential element for growth and subtilin formation by Bacillus subtilis. Archives of Biochemistry 15:13-17.

Jensen S E, Fecycz I T, Campbell J N 1980 Nutritional factors controlling exocellular protease production by Pseudomonas aeruginosa. Journal of Bacteriology 144:844-847.

Kessler E, Israel M, Landshman N, Chechick A, Blumberg S 1982 In vitro inhibition of Pseudomonas aeruginosa elastase by metal-chelating peptide derivatives. Infection and Immunity 38:716-723.

Reynolds J A, Schlesinger M J 1969 Alterations in the structure and function of Escherichia coli alkaline phosphatase due to $\mathrm{Zn}^{2+}$ binding. Biochemistry 8: 588-593.

Riddle L M, Graham T E, Amborski R L 1981 Medium for the accumulation of extracellular hemolysin and protease by Aeromonas hydrophila. Infection and Immunity 33:728-733.

Riordan J F 1976 Biochemistry of zinc. Medical Clinics of North America 60:661-674.

Sack R B 1980 Enterotoxigenic Escherichia coli: identification and characterization. Journal of Infectious Diseases 142:279-286.

Sack D A, Sack R B 1975 Test for enterotoxigenic Escherichia coli using Y1 adrenal cells in miniculture. Infection and Immunity 11:334-336.

Sato H, Murata R 1973 Role of zinc in the production of Clostridium perfringens alpha toxin. Infection and Immunity 8:360-369.

Sato H, Yamakawa Y, Ito A, Murata R 1978 Effect of zinc and calcium ions on the production of alpha-toxin and proteases by Clostridium perfringens. Infection and Immunity 20:325-333.

Sugarman B 1983 Zinc and infection. Reviews of Infectious Diseases 5:137-147.

Sugarman B, Eps L R, Stenback W A 1982 Zinc and bacterial adherence. Infection and Immunity 37:1191-1199.

Trotman C N A, Greenwood C 1971 Effects of zinc and other metal ions on the stability and activity of Escherichia coli alkaline phosphatase. Biochemical Journal 124:25-30.

Vallee B L 1959 Biochemistry, physiology and pathology of zinc. Physiological Reviews 39:443-490.

Wegener W S, Romano A H 1963 Zinc stimulation of RNA and protein synthesis in Rhizopus nigricans. Science 142:1669-1670.

Williams R O, Loeb L A 1973 Zinc requirement for DNA replication in stimulated human lymphocytes. Journal of Cell Biology 58:594-601. 